\title{
PENGGUNAAN TEKNIK SHAPING DENGAN TOILET \\ TRAINING PADA ANAK AUTIS
}

\author{
Fitria Rachmawaty \\ Fakultas Psikologi \\ Universitas Merdeka Malang
}

\begin{abstract}
Autism is a mental disorder in children were much discussed recently. The development of autism also increased sharply in recent decades. Autism was first introduced in a paper in 1943 by an American psychiatrist named Leo Kanner. He found eleven children who have the same characteristics, that is not able to communicate and interact with other individuals and very indifferent to the environment outside of himself, and his behavior seemed like living in his own world. In this case use the method assessment techniques with observation and interviews, and supported by several psychological tests. Prominent features of autistic behavior itself is the difficulty in social interaction, communication language stereotyped or repetitive. Besides, the client still has not been able to express his desire, one of which is a small kekamar independently, for it will be used in this case shaping techniques in shaping the behavior of the new subjects in order to be better able to express his desire to go back to the room is small. Of the technique performed showed significant on the subject, namely the change of interesting hands accompanying teachers when they want to pee, to be able to say the word "paisa" when they want to pee.
\end{abstract}

Keywords : Autisme, Shaping, Toilet Training.

PSIKOISLAMIKA. Jurnal Psikologi Islam (JPI) copyright @ 2015 Pusat Penelitan dan Layanan Psikologi. Volume 12 Nomor 1 Tahun 2015

\section{PENDAHULUAN}

Prevalensi anak autisme mengalami peningkatan estimasi prevalensi autisme antara 4-5/10.000 individu. Berdasarkan penelitian diperkirakan prevalensi meningkat menjadi 10-12/10.000 individu (Faradz, 2003). Jumlah penyandang autisme mencapai $60 \%$ dari keseluruhan populasi anak dunia (Sousa, 2010). Gejala autisme sangat bervariasi, sebagian anak autisme berperilaku hiperaktif dan agresif atau menyakiti diri, tapi ada pula yang pasif. Mereka cenderung sangat sulit mengendalikan emosinya dan sering tempertantrum (menangis dan mengamuk). Tantrum merupakan gejala yang paling khas yang akan mempengaruhi interaksi anak di sekolahnya (Yayasan Autis Indonesia, 2009 dalam Ria, 2011).

Sampai saat ini para ahli belum menentukan apa penyebab Special Needs. Namun beberapa ahli berpendapat McCandless (2003) Special Needs merupakan sindroma yang disebabkan oleh berbagai penyebab seperti :

1) Faktor genetik, diduga karena kromososm (ditemukan pada 5-20\% penyandang Autis) seperti kelainan kromososm yang disebut syndrome fragile - $\mathrm{x}$.

2) Kelalaian otak, adanya kerusakan atau berkurangnya jumlah sel syaraf yang disebut sel purkenye.

3) Kelainan neurotransmitter, terjadi karena impuls listrik antar sel terganggu alirannya.

4) Kelainan peptida pada otak. Dalam keadaan normal, gluten (protein gandum) dan kasein (protein susu) dipecah dalam usus menjadi peptida dan asam amino. Sebagian kecil peptida tersebut diserap di usus dan kemudian beredar dalam darah, bila berlebihan akan dikeluarkan melalui urine. Sebagian lainnya akan disaring kembali saat melewati batang darah otak, sehingga yang masuk ke dalam otak hanya sedikit dan berperan dalam 
peningkatan jumlah endorfin dan enfekali yang dibutuhkan dalam pengaturan aktifitas otak. Bila kadar endoruin dan enkefalin melebihi kebutuhan akan menyebabkan gangguan perilaku, persepsi, intelegensia emosi dan perasaan. Pada sebagian besar penyandang Autis turunan peptida yaitu gliadorpin dan casomorphin dalam urin jumlahnya berlebih yang menunjukkan adanya kelebihan peptida pada darah dan otak.

5) Komplikasi saat ibu hamil dan persalinan. Komplikasi yang terjadi seperti pendarahan pada trisemester pertama gawat janin yang disertai terhisapnya cairan ketuban yang bercampur feses dan obat-obatan yang diminum ibu selama kehamilan.

6) Kekebalan tubuh. Terjadi karena kemungkinan adanya interaksi gangguan kekebalan tubuh dengan faktor lingkungan.

7) Keracunan. Keracunan yang paling banyak dicurigai adalah karena keracunan logam berat timah hitam (plumbum), arsen, antimoni, kadmium dan merkuri yang berasal dari polusi udara, air maupun makanan.

8) Kejang. Setelah mengalami kejang beberapa anak menunjukkan gejala Autis (Novia \& Kurniawan, 2007).

Tidak semua anak menunjukkan gejala yang sama ataupun sama berat. Autistik untuk diagnosis kasus gangguan autistik yang berat dan memenuhi kriteria Diagnostic and Statistical Manual-IV (DSMIV). Orang tua sangat berperan dalam membina komunikasi dengan para guru di sekolah. Hal ini dikarenakan kerja sama orang tua dengan para guru, keterbukaan orang tua tentang kondisi anak, dan kesediaan untuk mengikuti berbagai program guna kemajuan anaknya. Gangguan perkembangan autisme adalah ketidakmampuan anak dalam berinteraksi dengan orang lain akibat penguasaan bahasa yang tertunda, mutism (penolakan berbicara), ecolalia (membeo), keinginan yang obsesif, rigid routines (keteraturan lingkungan), serta adanya aktivitas bermain yang bersifat repetitive (menimbulkan masalah nyeri) dan streotip (menimbulkan prasangka/ kecurigaan) (Safaria, 2005).

Hasil survey dari lima orangtua anak penyandang autisme menyatakan bahwa kelima orangtua merasa sangat kesulitan untuk merawat anak autisme, terkadang mereka sama sekali tidak mengetahui apa yang diinginkan oleh anak. Anak kesulitan bersosialisasi dengan orang lain terutama dalam mengungkapkan keinginan dan permasalahannya, sehingga terkadang anak mengekspresikan kesulitannya dengan cara tantrum. Anak juga mempunyai masalah untuk berhias, toileting, bersikap ataupun belajar (Noor; dkk, 2014).

Kemandirian anak salah satunya yaitu mengenai bantu diri, makan, minum, mandi, maupun kebutuhan toileting. Ginanjar (2008), mengemukakan bahwa strategi pelatihan toilet training pada anak autisme yaitu dengan menggunakan alat bantu visual sesuai dengan taraf pemahaman pada anak. Alat bantu visual yang ditampilkan dalam bentuk foto, tanda atau gambar bertulisan yang menunjukkan kapan anak harus ke kamar mandi dan urutan kegiatan apa saja yang harus dilakukan anak pada saat melakukan kegiatan toileting.

Survey dari 100 anak dengan gangguan autism di Amerika dengan usia rata-rata 19 tahun dilaporkan bahwa $22 \%$ mengalami kegagalan untuk pergi ketoilet dalam cakupan teknik mencuci tangan ataupun membersihkan kotoran. Anak dengan gangguan autis memiliki masalah pada proses sensori terhadap kontrol kandung kemih dan usus (Yip\&Kuo, 2013).

Pembelajaran metode demonstrasi sangat berpengaruh dalam pembelajaran toilet training pada anak. Selain itu kesiapan anak serta pengetahuan orang tua sangat berperan dalam proses toilet training (Binawarti, 2006; Luqmansyah, 2010).

Gambaran atau ciri autisme dimiliki oleh siswa salah satu Sekolah Dasar di Malang yang menjadi subjek dalam studi ini. Sekolah menengah tempat BT belajar adalah sekolah dasar inklusi, dimana BT dapat belajar bersama dan bersosialisasi dengan teman-teman non ABK. Hasil assesment menunjukkan suara yang keluar dari BT sangat pelan dan terkadang tidak menjawab ketika diajak bicara. Kemudian BT memunculkan perilaku stereotip pada minat dan aktivitas yaitu sering mengulangngulang pembicaraan. Atau ketika menginginkan sesuatu hanya mengulang-ngulang kata-kata. Dalam prestasi akademik BT tertinggal dibandingkan anak seusianya, namun ketika disuruh membaca, menulis dan berhitung BT sudah bisa melakukannya. Ketika dilakukannya tes WISC pada bagian informasi, BT cenderung menatap diam pemeriksa dan tidak bisa menjawab pertanyaan. BT hanya diam atau mengulang-ngulang apa yang diucapkan pemeriksa, dan ketika pada bagian mengerjakan simbol, BT mampu melakukannya meskipun dengan waktu yang cukup lama.

BT mengalami hambatan dalam inisiatif untuk kekamar mandi ketika ingin membuang air kecil 
maupun besar, subyek hanya menahannya dengan mengapitkan kedua paha sembari menggerakkan kedua kakinya atau mencubit guru pendampingnya. Kemudian jika ingin buang air besar, maka gejala yang timbul hanya tercium bau dari buang angin yang dilakukan BT. Jika sudah terjadi seperti itu, pendamping BT menyuruh BT untuk kekamar kecil. BT bisa melakukannya sendiri ketika dikamar kecil, meskipun terkadang BT sering lupa untuk menutup resleting celana setelah keluar dari kamar kecil. Jika sudah terjadi demikian, maka pendampingnya menyuruh subyek untuk kekamar, subyek mampu melakukannya sendiri ketika berada di toilet, meskipun terkadang subyek sering lupa untuk menutup resleting celana setelah keluar dari toilet. BT memiliki karakter cenderung pasif, adanya hambatan dalam interaksi sosial, yaitu ketika diajak berbicara, suara yang keluar sangat pelan dan terkadang tidak menjawab ketika diajak bicara.

Permasalahan yang dialami subyek ini disamping karena adanya gangguan autis yang dialaminya, ternyata juga diakibatkan oleh hubungan interaksi yang jarang dan kurang pada subyek. Adanya perceraian kedua orang tua subyek serta kesibukkan ibu E sebagai wanita karir, mengakibatkan kurangnya interaksi antara orang tua dan anaknya, sehingga proses pembelajaran perilaku yang diterima anak tidak semaksimal ketika adanya interaksi yang berkualitas pada kedua orang tua yang memberikan perhatian yang cukup pada anaknya, terlebih subyek mengalami gangguan autis yang sangat memerlukan perhatian khusus dari kedua orang tua dan lingkungan sekitar dalam membentuk perilakunya.

Seringkali orangtua tidak terlalu memahami mengenai anak Autis sehingga mereka merasa bimbang terhadap kondisi anaknya dan mengalami konflik dalam diri orangtua itu sendiri. Konflik tersebut terkait dengan keinginan dan harapan yang tidak terpenuhi untuk memiliki anak yang bisa dibanggakan dalam lingkungan. Ketidaksesuaian terjadi antara kenyataan dan idealisme (Novia \& Kurniawan, 2007).

Berdasarkan uraian di atas, maka rumusan permasalahan yang diajukan dalam penulisan ini adalah "apakah terapi shaping dengan toilet training efektif untuk meningkatkan kemandirian anak pada penderita autisme."

\section{METODE}

Metode yang digunakan dalam studi ini adalah observasi, wawancara, dan tes psikologi. Observasi dilakukan pada saat wawancara, kegiatan seharihari BT di sekolah, di rumah, serta pada saat pemeriksaan psikologis. Tujuan dari penggunaan metode observasi untuk melihat pola perilaku dan ekspresi BT dalam segala situasi.

Wawancara dilakukan dengan BT (autoanamnesa), orang tua, guru-guru BT di sekolah (alloanamnesa). Tujuan dari wawancara ini adalah untuk mengumpulkan data-data terkait dengan BT guna menunjang dalam melakukan penegakan diagnosis dari permasalahan BT.

Di samping kedua metode di atas, tes psikologi juga digunakan untuk memperkuat hasil wawancara dan observasi pada BT. Tes psikologi juga bertujuan untuk mengases hal-hal yang tidak ditampakkan BT seperti taraf inteligensi dan kapasitas mental BT. Tes psikologi yang diberikan pada BT adalah WISC.

\section{HASIL}

Banyak sekali penelitian yang dilakukan untuk memastikan apakah sebenarnya faktor penyebab dari autisme. Penelitian di bidang neuro-anatomi, neurofisiologi, neurokimia, dan genetik pada penyandang autisme menemukan fakta adanya gangguan neurobiologis pada penyandang autisme. Autisme disebabkan oleh gangguan atau kelainan pada perkembangan sel-sel otak selama dalam kandungan. Saat pembentukan sel-sel tersebut, timbul gangguan dari virus, jamur, oksigenasi (perdarahan), keracunan makanan ataupun inhalasi (keracunan pernafasan), yang menyebabkan pertumbuhan otak tidak sempurna. Penyebab kelainan neuro-anatomis: faktor genetik (keturunan), infeksi jamur dan virus, kekurangan nutrisi, oksigenasi, polusi udara, polusi air dan makanan.

Gangguan tersebut diyakini terjadi pada usia kehamilan 0-4 bulan sehingga menyebabkan kelainan anatomis pada lobus parietalis, cerebellum dan sistem limbik. Dari sekian banyak faktor yang menjadi penyebab dari autis pada subyek BT, salah satunya yang menjadi penyebabnya adalah pola makan ibu BT yang sering mengkonsumsi makanan instant atau kaleng serta makanan cepat saji yang banyak mengandung MSG monosodium glutamat) ketika mengandung subyek, hal ini dikarenakan ibu BT adalah seorang wanita karier dengan berbagai macam kesibukan yang tidak sempat untuk memasak dirumah. Selain itu faktor yang bisa dipertimbangkan adalah ketika hamil BT, ibu E sering pergi kesalon untuk menstylist rambutnya setiap tiga hari sekali, seperti mewarnai rambut atau sekedar untuk berkeramas. Disamping hal itu, 
ayah BT adalah seorang perokok berat sehingga memungkinkan adanya polusi udara yang terjadi pada ibu E ketika hamil BT yang menjadi faktor penunjang dari penyebab terjadinya gangguan autis pada subyek. Simon \& Morley (2002) mengatakan faktor lingkungan saat ini sedang diselidiki sebagai faktor risiko untuk autisme. Ini termasuk timah dan keracunan merkuri, konsumsi alkohol ibu, obat penyalahgunaan dan merokok, paparan asam valproik atau thalidomide sangat awal kehamilan, dan pra-atau perinatal anoxia / asfiksia, serta berbagai jenis virus dalam rahim infeksi. Pemahaman bahasa juga biasanya sangat terganggu seperti yang dijelaskan oleh Waterhouse \& Fein (1982), bahasa ekspresif biasanya lebih maju dari pada bahasa reseptif. Walaupun anak-anak mungkin dapat ikuti petunjuk sederhana seperti "duduk," "datang ke sini," dan "makan", namun pada mereka mengalami kegagalan untuk mengembangkan pemahaman tentang petunjuk itu. Autisme ditandai dengan adanya penurunan dalam penggunaan perilaku nonverbal untuk mengatur interaksi sosial (misalnya, gerak tubuh, kontak mata), kurangnya kenikmatan berbagi dengan orang lain, dan kurangnya timbal balik sosial atau emosional (American Psychiatric Association, 2000). Dan gangguan terus-menerus ini mempengaruhi hubungan ibu-anak di masa remaja dan dewasa dan dampaknya terhadap keluarga (Travis \& Sigman, 1998). BT memiliki hambatan dalam kemampuan untuk berkomunikasi, ekspresi emosi serta kemampuan secara kognitif.

$\mathrm{Hal}$ ini dikarenakan gangguan mental autis yang dialami subyek. Subyek sering berperilaku stereotip atau berulang-ulang yaitu dengan mengepalngepalkan tangannya. Subyek merupakan gangguan autis dengan tipe pasif, hal ini terlihat dari perilaku subyek ketika berada disekolah, subyek cenderung diam, tenang dan penurut. Dalam hal prestasi belajar, subyek memiliki kapasitas IQ mental defective. Subyek sekarang duduk dikelas 6 Sekolah Dasar, sejauh ini subyek sudah mamp membaca, menulis dan berhitung.

Dalam kesehariannya, subyek menghabiskan waktunya disekolah, keperluan subyek seperti perlengkapan sekolah serta berangkat dan pulang sekolah dikerjakan oleh kakak laki-laki subyek atau pengasuh subyek, hal tersebut dikarenakan adanya perceraian kedua orang tua dan kedua orang tua yang sibuk bekerja sehingga menimbulkan kontak komunikasi secara verbal mapun nonverbal yang kurang. Dari hal tersebut maka menimbulkan proses belajar yang salah pada subyek. Subyek ketika berada dirumah tidak memiliki model dalam proses belajar dirumah yang tidak maksimal. Terlebih subyek mengalami gangguan mental autis yang sangat memerlukan perhatian serta terapi perilaku guna memaksimalkan kemandiria pada subyek. Karena adanya proses belajar tersebut, maka menimbulkan masalah pada subyek yaitu subyek tidak bisa mengungkapkan secara verbal keinginannya untuk pergi ke kamar kecil. Subyek hanya bisa menarik-narik pendampingnya atau mencubit ketika ingin ke kamar kecil.

Dilihat dari penyebab permasalahan kemandirian pada subyek, maka dapat dilakukan melalui pendekatan behavioristik yaitu hubungan yang kurang harmonis atau berkualitas antara kedua orang tua, terutama ibu dan anak, akan menyebabkan kurang maksimalnya perilaku kemandirian pada anak. Hal ini dikarenakan tidak adanya model secara khusus yang diterima oleh anak sehingga anak kurang bisa mempelajari tipe perilaku yang seharusnya bisa dilakukakan oleh anak. Terlebih pada subyek yang mengalami gangguan autis, butuh model dan perlakuan khusus dalam pembentukan perilaku pada anak. Untuk itu sangat dibutuhkan interaksi yang berkualitas antara ibu dan anak. $\mathrm{Hal}$ ini dikarenakan karena sangat rawannya permasalahan hubungan antara ibu dengan anak yang mengalami gangguan mental, seperti dalam penelitian yang dilakukan oleh (Essex, dkk, 2002) bahwa perilaku maladaptif pada orang dewasa dengan keterbelakangan mental dapat mengikis hubungan ibu dan anak dan akibatnya dapat mempengaruhi perasaan ibu tentang pengalaman pengasuhan. Karakteristik ibu tertentu juga memiliki telah terbukti memiliki efek pada hubungan ibu terhadap anak dan pengalaman pengasuhan, dengan demikian terdapat pula pengaruh dari ibu pesimisme, harga diri, serta status perkawinan. Hubungan ibu-anak telah menunjukkan terpengaruh oleh pesimisme ibu tentang masa depan anak (Bristol \& Schopler, 1983). Kualitas hubungan antara ibu dan anak memang merupakan faktor penting, ibu yang bisa mengendalikan karakteristik anak serta ibu yang mengasuh anak secara kuat akan memberikan pengaruh positif yang lebih besar terhadap putra atau putri mereka, hal ini menunjukkan pentingnya kualitas hubungan ibu dan anak untuk memelihara pengasuhan ibu serta kapasitas keluarga individu dengan gangguan spektrum autisme. Pada obsrvasi dan wawancara yang dilakukan, semua kebutuhan 
subyek yang mengurusnya adalah kakak laki-laki subyek, seperti mengantarkan kesekolah, memasak dan menyiapkan bekal kesekolah. Hal ini dikarenakan kesibukan ibu subyek yang bekerja dari pagi hingga sore hari.

Berdasarkan informasi yang diperoleh melalui observasi, wawancara dan tes inteligensi yang dilakukan, maka diagnosis yang dapat ditegakkan pada subjek BT (14 tahun), adalah sebagai berikut:

\section{Diagnosis}

Axis I : 299. 00 Autistic Disorder

(Masalah dalam toilet training)

Axis II : V71. 09 no diagnosis

Axis III : V71. 09 no diagnosis

Axis IV : Primary support group

(orang tua yang bercerai)

Axis $\mathrm{V} \quad: \mathrm{GAF}=51$

(moderate simptom, afek datar, berbicara yang tidak jelas, kesulitan sedang dalam fungsi sosial, fungsi sekolah, dan konflik bersama teman sebaya).

\section{Prognosis}

Faktor yang meringankan pada keadaan subyek adalah : Subyek merupakan tipe anak autis yang pasif dan menurut, lingkungan sekolah yang mendukung dalam perubahan perilaku subyek.

Faktor yang memberatkan pada keadaan subyek adalah : Perceraian kedua orang tua dan ibu yang kurang memiliki waktu untuk subyek. Adanya faktor-faktor yang memberatkan dan faktor pendukung pada subyek, maka prognosis adalah sedang.

\section{Intervensi}

Tujuan : Memberikan teknik shaping guna melatih serta meningkatkan perilaku subyek dalam mengutarakan keinginannya untuk pergi kekamar kecil.

\section{DISKUSI}

Dalam kasus ini akan digunakan teknik shaping dalam mengubah perilaku subyek dari kesulitan dalam mengungkapkan keinginan untuk pergi ke toilet, tidak hanya dilakukan disekolah, tetapi juga diharapkan dapat dilakukan dirumah dengan didampingi oleh ibu subyek sehingga secara otomatis pula diharapkan mampu meningkatkan hubungan yang berkualitas antara ibu dan subyek. Eisenberg (2001) menjelaskan bagaimana lingkungan menjadi faktor seperti pengaruh ibu khusus positif, bisa mempengaruhi jalannya perkembangan perilaku antara individu dengan risiko biologis untuk perilaku masalah. Proses keluarga yang positif juga mungkin berpengaruh dalam mempromosikan kesehatan mental dan mengurangi simtomatologi selama masa dewasa. Misalnya, hubungan antara lingkungan keluarga yang positif dan hasil lebih optimal telah ditunjukkan dalam studi individu dengan skizofrenia dan keluarga mereka. Hasil penelitian dari Seltzer, Shattuck, Abbeduto, \& Greenberg (2004) menekankan peran penting positif interaksi orangtua-anak dalam mengurangi gejala dan masalah perilaku pada remaja dan orang dewasa dengan autisme. Shattuck (2007) mengatakan iklim keluarga yang positif dapat menjadi tambahan mekanisme perubahan perilaku yang berulang, faktor-faktor lingkungan memiliki arti-penting untuk perilaku repetitif selain untuk komunikasi atau kemampuan sosial.

Essex dkk (2002) bahwa perilaku maladaptif pada orang dewasa dengan keterbelakangan mental dapat mengikis hubungan ibu dan anak dan akibatnya dapat mempengaruhi perasaan ibu tentang pengalaman pengasuhan. Karakteristik ibu tertentu juga memiliki telah terbukti memiliki efek pada hubungan ibu terhadap anak dan pengalaman pengasuhan, dengan demikian terdapat pula pengaruh dari ibu pesimisme, harga diri, serta status perkawinan. Menurut Bristol \& Schopler (1983), hubungan ibu-anak telah menunjukkan terpengaruh oleh pesimisme ibu tentang masa depan anak. Kualitas hubungan antara ibu dan anak memang merupakan faktor penting, ibu yang bisa mengendalikan karakteristik anak serta ibu yang mengasuh anak secara kuat akan memberikan pengaruh positif yang lebih besar terhadap putra atau putri mereka, hal ini menunjukkan pentingnya kualitas hubungan ibu dan anak untuk memelihara pengasuhan ibu serta kapasitas keluarga individu dengan gangguan spektrum autisme.

Pada obsrvasi dan wawancara yang dilakukan, semua kebutuhan subyek yang mengurusnya adalah kakak laki-laki subyek, seperti mengantarkan kesekolah, memasak dan menyiapkan bekal kesekolah. Hal ini dikarenakan kesibukan ibu subyek yang bekerja dari pagi hingga sore hari. Dalam kasus ini akan digunakan teknik shaping dalam mengubah perilaku subyek dari kesulitan dalam mengungkapkan keinginan untuk pergi ke toilet, tidak hanya dilakukan disekolah, tetapi juga diharapkan dapat dilakukan dirumah dengan 
didampingi oleh ibu subyek sehingga secara otomatis pula diharapkan mampu meningkatkan hubungan yang berkualitas antara ibu dan subyek.

\section{Teknik Shaping}

Dalam pembentukkan respons, tingkah laku sekarang secara bertahap diubah dengan memperkuat unsur-unsur kecil dari tingkah laku baru yang diinginkan secara berturut-turut sampai mendekati tingkah laku akhir. Pembentukkan respons berwujud pengembangan suatu respons yang pada mulanya yang tidak dapat dalam perbendaharaan tingkah laku individu (Jones, 2011). Jika terapis menginginkan adanya penambahan perilaku dengan segera, maka diberikannya jadwal secara terus-menerus dan diberi pengukuh yang kuat (Soekadji, 1983). Perkuatan sering digunakan dalam proses pembentukan respons ini. Maka jika pemeriksa ingin melatih subyek dalam mengutarakan keinginannya untuk pergi kekamar kecil, maka di sela-sela waktu terapi ataupun setelah dilakukannya terapi, pemeriksa memberikan pujian ketika mendampingi BT dalam belajar mengutarakan keinginannya. Pemeriksa disini lebih memberikan penguatan-penguatan dalam proses pendampingan belajar tersebut.

Dalam memodifikasi perilaku memiliki keunggulan dikarenakan prosesnya yang direncanakan serta disetujui oleh subyek sehingga berpotensi dalam peningkatan perubahan perilaku yang lebih baik lagi (Soekadji, 1983). Berdasarkan gejala yang dialami oleh BT adalah ia mengalami hambatan dalam perilaku verbal untuk mengutarakan keinginannya ke toilet sehingga jika dikemudian hari subyek tidak bersama orang-orang yang mengerti keadaannya, maka dikhawatirkan akan terjadi masalah pada subyek. Untuk itu dilakukannya teknik shaping dalam mengubah perilaku yang lama untuk menjadi

\section{KEPUSTAKAAN}

American Psychiatric Association (APA). (2010). Diagnostic and Statistical Manual of Mental Disorder Fourth Edition Text Revision (DSM IV-TR). Washington: American Psychiatric Association (APA).

Binarwati, D. (2006). Pengaruh pembelajaran metode demonstrasi terhadap perilaku orang tua dan kemampuan toilet training pada anak usia 1 tahun sampai dengan 3 tahun. Diperoleh tanggal 09 Agustus 2012 dari http:// ners. unair. ac.id/materikuliah/5-tugas-metrisnursalam.pdf. perilaku yang baru pada subyek. Dalam teknik ini perubahan yang dilakkan masih pada tahap awal dengan mengubah perilaku secara verbal yang dahulu subyek hanya mampu mencubit dan menarik tangan ketika ingin pergi ke kamar kecil, maka sekarang subyek ketika ditanya sudah mampu menjawab dan mengutarakan keinginannya. Dari teknik shaping yang dilakukan selama 8 sesi pada subyek ketika berada disekolah cukup memberikan hasil yang signifikan yaitu adanya perubahan perilaku secara verbal seperti subyek cukup mampu mengucapkan kata "pis". Meskipun kata-kata yang diucapkan belum sempurna seperti kata "pipis" namun hal tersebut cukup memberikan peningkatan perilaku yang positif dan signifikan bagi anak yang mengalami gangguan mental autis. Perubahan ini memberikan kesan tersendiri bagi pihak sekolah, terutama pada guru pendamping subyek.

\section{KESIMPULAN}

Dari dilakukannya teknik observasi, didapatkan hasil berupa BT memiliki karakter cenderung pasif. Adanya hambatan dalam interaksi sosial, yaitu ketika diajak berbicara, suara yang keluar sangat pelan dan terkadang tidak menjawab ketika diajak bicara, dengan diagnosis gangguan autis. Dari gangguan tersebut memunculkan permasalahan dalam toilet training. Untuk itu digunakannya teknik shaping guna melatih serta meningkatkan perilaku subyek dalam mengutarakan keinginannya untuk pergi kekamar kecil. Dari teknik shaping yang dilakukan selama 8 sesi pada subyek ketika berada disekolah cukup memberikan hasil yang signifikan yaitu adanya perubahan perilaku secara verbal yang cukup membaik.

Cohen., S. B. (2001). Theory of mind in normal development and autism. Journal appeared in Prisme (34) 174-183.

Faradz S.M.H. (2003) "Konferensi Nasional Autisme-1". Jakarta. Perhimpunan Dokter Spesialis Kedokteran Jiwa Indonesia.

Greenberg., Orsmond., Krauss. (2006). Mother-Child Relationship Quality Among Adolescents and Adults With Autism. American Journal On Mental Retardation, (2) 121-137.

Ginanjar, A. (2007). Memahami spektrum autistik secara holistik. Jakarta: Fakultas Psikologi 
Universitas Indonesia.

Kaplan, I.H., Sadock, M.D., \& Grebb, A.J. (2010). Sinopsis Psikiatri. Tangerang : Binarupa Aksara

Ria, R. T. (2011). Pengalaman ibu merawat anak autistik dalam memasuki masa remaja di Jakarta. Diperoleh pada tanggal 13 Juni 2014 dari fpbs.upi.edu.

Safaria, T. (2005). Autisme pemahaman baru untuk hidup bermakna bagi orang tua. Yogyakarta: Graha Ilmu.

Simon, B. C., Leslie, A. M. , Frith, U. (1985). Does the autistic child have a "theory of mind"?. Journal of Cognitif Development, 2 (2) 37-46.

Smith, L. E., Jan., \& Seltzer., M. M. (2008). Symptoms and Behavior Problems of Adolescents and Adults With Autism: Effects of Mother-Child Relationship Quality, Warmth, and Praise. American Journal On Mental Retardation, 113 (5) 387-402.
Lund., S. K., Pelios., L. V. (2001). A Selective Overview of Issues on Classification, Causation, and Early Intensive Behavioral Intervention for Autism. Jornal Of Behavior Modification, 25 (5) 678-697.

Lidsky., T. I., Schneider,. J. S. (2005). Autism and Autistic Symptoms Associated with Childhood Lead Poisoning. The Journal of Applied Research, 5 (1) 2005.

Luqmansyah. (2010). Hubungan tingkat pengetahuan ibu tentang toilet training dengan penerapan toilet training pada anak usia toddler di Kelurahan Mijen Kecamatan Mijen Kota Semarang. Diperoleh tanggal 09 Agustus 2012 dari http://jtptunimus-gdl-luqmansyah-52153-bab2 jtptunimus-gdl-luqmansyah-5215-3bab2.com.

Zachor., D. A., Itzchak., E. B. (2010). Treatment Approach, Autism Severity And Intervention Outcomes In Young Children. Journal of Elsevier, (4) 425-432. 